\title{
Synthesis, Characterization and X-Ray Structure of a Ba(II)/Ag(I)/Cr(III)-Oxalate Salt with Water-Filled Nanochannels
}

\author{
Clémence Eboga Tanke1, Bridget N. Ndosiri1 ${ }^{1}$ Yves A. Mbiangué2, Gouet Bebga ${ }^{3 *}$, \\ Justin Nenwa ${ }^{1}$ \\ ${ }^{1}$ Inorganic Chemistry Department, Faculty of Science, University of Yaounde 1, Yaounde, Cameroon \\ ${ }^{2}$ Chemistry Department, Higher Teacher Training College, University of Maroua, Maroua, Cameroon \\ ${ }^{3}$ Chemistry Department, Higher Teacher Training College, University of Yaounde 1, Yaounde, Cameroon \\ Email: "gouetbeb@yahoo.fr
}

Received 11 December 2015; accepted 22 January 2016; published 25 January 2016

Copyright (C) 2016 by authors and Scientific Research Publishing Inc.

This work is licensed under the Creative Commons Attribution International License (CC BY).

http://creativecommons.org/licenses/by/4.0/

(c) (i) Open Access

\begin{abstract}
A novel mixed barium(II)/silver(I)/chromium(III) oxalate salt, $\mathrm{Ba}_{0.5} \mathrm{Ag}_{2}\left[\mathrm{Cr}\left(\mathrm{C}_{2} \mathrm{O}_{4}\right)_{3}\right] \cdot 5 \mathrm{H}_{2} \mathrm{O}$ (1), with open architecture has been synthesized in water and characterized by elemental analysis, vibrational and electronic spectra, and single crystal $X$-ray structure determination. Compound 1 crystallizes in a monoclinic space group $C 2 / c$, with unit cell parameters $a=18.179(3), b=14.743(2)$, $c$ $=12.278(2) \AA, \beta=113.821(3)^{\circ}, \mathrm{V}=3010.34(90) \AA^{3}, \mathrm{Z}=8$. The structure is characterized by a network of anionic $\left[\mathrm{Cr}\left(\mathrm{C}_{2} \mathrm{O}_{4}\right)_{3}\right]^{3-}$ units connected through the $\mathrm{O}$ atoms of the oxalates to $\mathrm{Ba}^{2+}$ and $\mathrm{Ag}^{+}$ sites, forming a three-dimensional coordination polymer with one-dimensional isolated nanochannels parallel to the c axis, and encapsulating hydrogen-bonded guest water molecules. The bulk structure is consolidated by $0-\mathrm{H} \cdots \mathrm{O}$ bridgings within the nanochannels and by coulombic interactions.
\end{abstract}

\section{Keywords}

Crystal Structure, Chromium(III) Complex, Nanochannels, Coordination Polymer, Guest-Water Molecules

\section{Introduction}

Open-framework materials have drawn increasing attention over the past few years not only because of the wide

${ }^{*}$ Corresponding author.

How to cite this paper: Tanke, C.E., Ndosiri, B.N., Mbiangué, Y.A., Bebga, G. and Nenwa, J. (2016) Synthesis, Characterization and X-Ray Structure of a $\mathrm{Ba}(\mathrm{II}) / \mathrm{Ag}(\mathrm{I}) / \mathrm{Cr}(\mathrm{III})$-Oxalate Salt with Water-Filled Nanochannels. American Journal of Analytical Chemistry, 7, 99-106. http://dx.doi.org/10.4236/ajac.2016.71010 
diversity in structures, but also for their potential applications as functional materials in the areas of catalysis, magnetism, non-linear optics, gas storage and separation processes [1]-[6]. Amongst multidentate ligands usually engaged in the construction of this class of materials, the oxalate $(2-)$ dianion $\left(\mathrm{C}_{2} \mathrm{O}_{4}^{2-}\right)$ occupies an important place, since it is one of the simplest imaginable connectors potentially able to bridge metals ions in the bidentate chelating manner. Major emphasis in studies employing this highly versatile ligand is associated with the formation of exotic network structures. Transition metal ion complexes provide useful building blocks for stereochemistry control. In this process, the well-documented tris(oxalato)chromate(III) ion, $\left[\mathrm{Cr}\left(\mathrm{C}_{2} \mathrm{O}_{4}\right)_{3}\right]^{3-}$, plays a crucial role based on: 1) its remarkable nature as a chiral and paramagnetic building block, 2) its ability to function as a metalloligand (or auxillary ligand) that can mediate electronic effects between paramagnetic centers (e.g. magnetic interactions), and 3) its ability to form interesting long-range hydrogen-bonded solid-state networks.

Over the last decade, the family of materials with a variable Ag-Cr-oxalate channel lattice, formulated generally as $\left[\left(\mathrm{M}_{\mathrm{x}} \mathrm{Ag}_{0.50-\mathrm{x}}\right)\left(\mathrm{H}_{2} \mathrm{O}\right)_{3}\right] @\left[\mathrm{Ag}_{2.50} \mathrm{Cr}\left(\mathrm{C}_{2} \mathrm{O}_{4}\right)_{3}\right](0 \leq \mathrm{x} \leq 0.50 ; \mathrm{M}=\mathrm{K}, \mathrm{Cs}, \mathrm{Ag})$, has been at the focus of interest in contemporary research and development [7]. These silver salts generally crystallize in a nonmolecular polymer framework preferentially with flexible deficiencies $\mathrm{x}$ of $\mathrm{Ag}^{+}$ions, thus generating a negatively charged lattice grid. They share in their crystal structures a one-dimensional channel lattice as their characteristic feature.

Along the lines of our progressing research program, we recently reported some closely related channel lattice networks with chemical compositions $\left[\mathrm{Ag}_{3-\mathrm{x}} \mathrm{Cr}\left(\mathrm{C}_{2} \mathrm{O}_{4}\right)_{3}\right]^{\mathrm{x}}$, where the negative charge $(-\mathrm{x})$ is offset by an equivalent fractional charge from protons [8], monoatomic cations $\left(\mathrm{M}^{+}\right)$from group 1 elements [9] [10] or from metal(III) ions [11]. In connection with these results, we have been investigating other silver/chromium-oxalate compounds with a view not only to produce new materials but also to unravel the subtle structural features that characterize these solids. During the course of these investigations, we have now isolated a novel Ag-Cr-oxalate channel lattice compound of the formula $\mathrm{Ba}_{0.5} \mathrm{Ag}_{2}\left[\mathrm{Cr}\left(\mathrm{C}_{2} \mathrm{O}_{4}\right)_{3}\right] \cdot 5 \mathrm{H}_{2} \mathrm{O}(\mathbf{1})$, in which the negative charge of the lattice grid with chemical composition $\left[\mathrm{Ag}_{2} \mathrm{Cr}\left(\mathrm{C}_{2} \mathrm{O}_{4}\right)_{3}\right]^{-}$is counterbalanced by a half $\mathrm{Ba}^{2+}$ cation. Herein, we describe the title compound as a useful precursor for the forthcoming metathetic syntheses of new compounds containing the negative lattice grid $\left[\mathrm{Ag}_{2} \mathrm{Cr}\left(\mathrm{C}_{2} \mathrm{O}_{4}\right)_{3}\right]^{-}$.

\section{Experimental Procedure}

\subsection{Chemical Preparation}

The purchased salts, silver nitrate (Riedel-de Haën, 99.5\%) and barium nitrate (Riedel-de Haën, 99.5\%) were used as received; the precursor salt $\mathrm{K}_{3}\left[\mathrm{Cr}\left(\mathrm{C}_{2} \mathrm{O}_{4}\right)_{3}\right] \cdot 3 \mathrm{H}_{2} \mathrm{O}$ was prepared using a literature method [12]. A mixture of $\mathrm{AgNO}_{3}(1.36 \mathrm{~g}, 8 \mathrm{mmol})$ and $\mathrm{Ba}\left(\mathrm{NO}_{3}\right)_{2}(0.53 \mathrm{~g}, 2 \mathrm{mmol})$ was dissolved in water $(50 \mathrm{~mL})$. The precursor salt $\mathrm{K}_{3}\left[\mathrm{Cr}\left(\mathrm{C}_{2} \mathrm{O}_{4}\right)_{3}\right] \cdot 3 \mathrm{H}_{2} \mathrm{O}(1.95 \mathrm{~g}, 4 \mathrm{mmol})$ was dissolved in water $(60 \mathrm{~mL})$. This latter solution was added dropwise into the former. The mixture was stirred at $60^{\circ} \mathrm{C}$ for $2 \mathrm{~h}$. The resulting violet solution was filtered and left to stand undisturbed in the hood at room temperature. After five days, elongated dark-violet crystals were harvested. Yield: $0.77 \mathrm{~g}(55.9 \%)$ based on $\mathrm{K}_{3}\left[\mathrm{Cr}\left(\mathrm{C}_{2} \mathrm{O}_{4}\right)_{3}\right] \cdot 3 \mathrm{H}_{2} \mathrm{O}$ salt. M.P.: $>250^{\circ} \mathrm{C}$. Elemental analysis: Calc. for $\mathrm{C}_{6} \mathrm{H}_{10} \mathrm{Ag}_{2} \mathrm{Ba}_{0.50} \mathrm{CrO}_{17}\left(690.55 \mathrm{~g} \cdot \mathrm{mol}^{-1}\right.$ ) C, 10.44; $\mathrm{H}, 1.46$. Found: $\mathrm{C}, 10.42 ; \mathrm{H}, 1.41$. These crystals are readily soluble in water. IR ( $\mathrm{KBr}, \mathrm{cm}^{-1}$ ): 3417 (broad), 1623 (sharp), 1375 (sharp), 1258 (sharp), 901 (sharp), 800 (sharp), 543 (sharp) and 409 (sharp). UV-Vis ( $\mathrm{H}_{2} \mathrm{O}$ solution, nm): 416; 568.

\subsection{Investigation Techniques}

\subsubsection{Elemental Analysis}

Elemental analysis (C, H) was performed on a VARIO EL (Heraeus) CHNS analyzer.

\subsubsection{Infrared Spectroscopy}

The infrared spectrum was recorded using a Nicolet Avater 360 FT-IR spectrometer in the range 4000 - 400 $\mathrm{cm}^{-1}$ with $\mathrm{KBr}$ (500 mg KBr/0.5 mg sample).

\subsubsection{Ultraviolet-Visible Spectroscopy}

The UV-Vis spectrum was recorded on an AQUALYTIC spectrophotometer, in water solution, in the range 300 $-800 \mathrm{~nm}$. 


\subsubsection{X-Ray Single Crystal Structural Analysis}

A shining violet crystal with approximate dimensions $0.20 \times 0.18 \times 0.12 \mathrm{~mm}^{3}$ was carefully selected in oil at room conditions and attached to the tip of a nylon loop. It was mounted in a stream of cold nitrogen and centered in X-ray beam by using a video camera. Crystal evaluation and X-ray data collection were performed on a model Xcalibur 3 diffractometer, equipped with $\mathrm{Mo} \mathrm{K} \alpha(\lambda=0.71073 \AA)$ radiation. The reflections obtained were indexed by an automated indexing routine built in the SMART program [13]. The highly redundant data sets were corrected for Lorentz and polarization effects. The collected data were reduced with SAINT [14] and an empirical absorption correction was carried out by using the SADABS program [15]. The crystal structure was solved by direct methods and refined by full-matrix least squares refinement [16], based on $F^{2}$. Crystal data and structure refinement parameters for $\mathbf{1}$ are given in Table 1, and selected bond lengths and angles in Table 2.

Table 1. Crystal data and structure refinement parameters for $\mathbf{1 .}$

\begin{tabular}{|c|c|}
\hline \multicolumn{2}{|r|}{ Crystal data } \\
\hline Chemical formula & $\mathrm{Ba}_{0.5} \mathrm{Ag}_{2}\left[\mathrm{Cr}\left(\mathrm{C}_{2} \mathrm{O}_{4}\right)_{3}\right] \cdot 5 \mathrm{H}_{2} \mathrm{O}$ \\
\hline $\mathrm{M}_{\mathrm{r}}$ & 690.55 \\
\hline Crystal system, space group & Monoclinic, C2/c \\
\hline Temperature (K) & 293(2) \\
\hline$a, b, c(\AA)$ & 18.179(3), 14.743(2), 12.278(2) \\
\hline$\beta\left(^{\circ}\right)$ & 113.821(3) \\
\hline $\mathrm{V}\left(\AA^{3}\right)$ & 3010.34(90) \\
\hline$Z$ & 8 \\
\hline$D_{\text {calc }}\left(\mathrm{Mg} / \mathrm{m}^{3}\right)$ & 2.979 \\
\hline Radiation type & $\mathrm{MoK} \alpha$ \\
\hline$\mu\left(\mathrm{mm}^{-1}\right)$ & 4.38 \\
\hline$F(000)$ & 2468 \\
\hline Crystal size (mm) & $0.20 \times 0.18 \times 0.12$ \\
\hline \multicolumn{2}{|c|}{ Data collection and refinement } \\
\hline Diffractometer & Bruker AXS SMART Xcalibur 3 diffractometer \\
\hline Absorption correction & Multi-scan with SADABS \\
\hline$\theta$ Range for data collection $\left({ }^{\circ}\right)$ & $1.84-28.40$ \\
\hline Index ranges & $-23<h<23,-19<k<17,-16<l<16$ \\
\hline Reflections collected & 15502 \\
\hline Independent reflections $\left(R_{\text {int }}\right)$ & $4870(0.0532)$ \\
\hline Completeness to $\theta=28.40^{\circ}(\%)$ & 98.9 \\
\hline Max. and min. transmission & 0.661 and 0.472 \\
\hline Refinement method & Full-matrix least squares on $F^{2}$ \\
\hline Data/restraints/parameters & $4870 / 1 / 247$ \\
\hline Goodness-of-fit on $F^{2}$ & 1.012 \\
\hline Final $R$ indices $[I>2 \operatorname{sigma}(I)]$ & $R_{1}=0.0433, \mathrm{w} R_{2}=0.0901$ \\
\hline$R$ indices (all data) & $R_{1}=0.0532, \mathrm{w} R_{2}=0.0976$ \\
\hline Largest diff. peak and hole $\left(\mathrm{e} \AA^{-3}\right)$ & 2.499 and -1.879 \\
\hline
\end{tabular}




\section{Results and Discussion}

\subsection{Elemental Analysis of Compound 1}

Elemental and full X-ray structure analyses converge to support the formulation of compound $\mathbf{1}$ as $\mathrm{Ba}_{0.5} \mathrm{Ag}_{2}$ $\left[\mathrm{Cr}\left(\mathrm{C}_{2} \mathrm{O}_{4}\right)_{3}\right] \cdot 5 \mathrm{H}_{2} \mathrm{O}$. This fact of matter unambiguously demonstrates that the single crystal used for the X-ray structure determination is representative of the entire complex synthesized.

\subsection{IR Spectrum of 1}

The FTIR spectrum of compound 1 (Figure 1) shows a broad absorption band around $3417 \mathrm{~cm}^{-1}$ which is assigned to water molecules within the channels. The bands centered at $1623 \mathrm{~cm}^{-1}$ and $1375 \mathrm{~cm}^{-1}$ are attributed to

Table 2. Selected bond distances $(\AA)$ and angles $\left(^{\circ}\right)$ of the anionic complex $\left[\mathrm{Cr}\left(\mathrm{C}_{2} \mathrm{O}_{4}\right)_{3}\right]^{3-}$ in $\mathbf{1}$.

\begin{tabular}{cccc}
\hline Cr4-O1 & $1.977(5)$ & Cr4-O6 & $1.970(6)$ \\
Cr4-O3 & $1.982(6)$ & Cr4-O7 & $1.977(6)$ \\
Cr4-O4 & $1.964(6)$ & Cr4-O8 & $1.965(6)$ \\
O6-Cr4-O1 & $91.3(2)$ & O4-Cr4-O6 & $93.8(3)$ \\
O7-Cr4-O1 & $81.7(2)$ & O8-Cr4-O6 & $94.5(2)$ \\
O4-Cr4-O3 & $93.3(3)$ & O4-Cr4-O7 & $93.6(3)$ \\
O8-Cr4-O3 & $174.7(2)$ & O8-Cr4-O7 & $91.5(3)$ \\
O6-Cr4-O3 & $82.4(2)$ & O6-Cr4-O7 & $171.0(2)$ \\
O7-Cr4-O3 & $92.1(2)$ & O4-Cr4-O1 & $173.6(3)$ \\
O1-Cr4-O3 & $91.2(2)$ & O8-Cr4-O1 & $93.2(2)$ \\
O4-Cr4-O8 & $82.5(2)$ & & \\
\hline
\end{tabular}

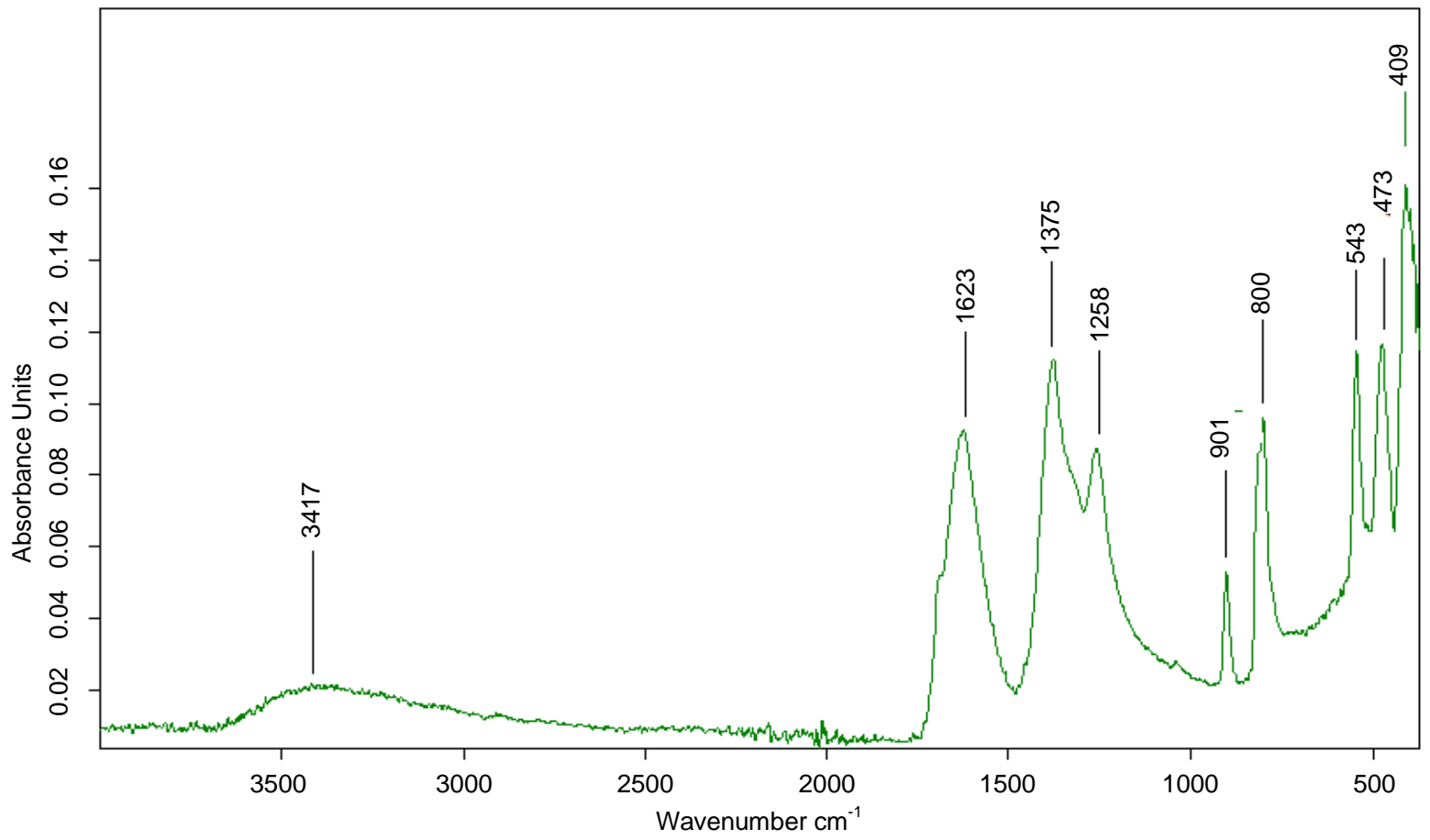

Figure 1. Infrared absorption spectrum of compound $\mathbf{1}$. 
$v(\mathrm{C}=\mathrm{O})$ and $v(\mathrm{C}-\mathrm{O})$ stretches respectively [8]-[11]. The bands centered at $900 \mathrm{~cm}^{-1}$ and $800 \mathrm{~cm}^{-1}$ are attributed to C-C stretches. The sharp band observed at $543 \mathrm{~cm}^{-1}$ can be assigned to the $\mathrm{Cr}-\mathrm{O}$ vibration [8] [9] and the band at $409 \mathrm{~cm}^{-1}$ to the Ba-O vibration [17].

\subsection{Ultraviolet-Visible Spectrum of 1}

The UV-Vis spectrum of compound 1 (Figure 2) displays two absorption bands centered at 416 and $568 \mathrm{~nm}$, which are due to $d$ - $d$ electronic transitions within the octahedral complex ions $\left[\mathrm{Cr}\left(\mathrm{C}_{2} \mathrm{O}_{4}\right)_{3}\right]^{3-}$ contained in $\mathbf{1}$ [8] [9] [17]. It is obvious that the present electronic absorption spectrum is virtually superimposable with that reported since the spectral informations thus obtained solely relate to the $\left[\mathrm{Cr}\left(\mathrm{C}_{2} \mathrm{O}_{4}\right)_{3}\right]^{3-}$ species.

\subsection{Crystal Structure of Compound 1}

The X-ray structure determination of 1 reveals the chemical formulation $\mathrm{Ba}_{0.5} \mathrm{Ag}_{2}\left[\mathrm{Cr}\left(\mathrm{C}_{2} \mathrm{O}_{4}\right)_{3}\right] \cdot 5 \mathrm{H}_{2} \mathrm{O}$. Compound $\mathbf{1}$ is a nonmolecular material that crystallizes in a nanoporous structure in which infinite one-dimensional channels run parallel to the crystallographic $c$-axis, each channel (diameter ca. $8.27 \AA$ ) being well isolated from its nearest neighbors by thick walls of the three-dimensionally connected network of $\mathrm{Ba}^{2+}$ and $\mathrm{Ag}^{+}$cations and $\left[\mathrm{Cr}\left(\mathrm{C}_{2} \mathrm{O}_{4}\right)_{3}\right]^{3-}$ complex anions. Hydrogen-bonded water molecules are found in the channels. Figure 3 is a balland-stick representation of the unit cell of $\mathbf{1}$, projected onto the $a b$-plane highlighting water molecules within the channels and showing clearly that the host lattice consists exclusively of $\mathrm{Ba}^{2+}$ and $\mathrm{Ag}^{+}$cations and $\left[\mathrm{Cr}\left(\mathrm{C}_{2} \mathrm{O}_{4}\right)_{3}\right]^{3-}$ complex anions. Compound 1 represents a new member of the broad family of silver-deficient oxalatometalate(III) salts with water-filled nanochannels generally formulated as $\left[\left(\mathrm{M}_{\mathrm{x}} \mathrm{Ag} \mathrm{g}_{0.50-\mathrm{x}}\right)\left(\mathrm{H}_{2} \mathrm{O}\right)_{3}\right] @\left[\mathrm{Ag}_{2.50} \mathrm{Cr}\left(\mathrm{C}_{2} \mathrm{O}_{4}\right)_{3}\right](0$ $\leq \mathrm{x} \leq 0.50 ; \mathrm{M}=\mathrm{K}, \mathrm{Cs}, \mathrm{Ag})[7]$.

The constitutive ionic building blocks of the structure of $\mathbf{1}-$ the $\left[\mathrm{Cr}\left(\mathrm{C}_{2} \mathrm{O}_{4}\right)_{3}\right]^{3-}$ complex, the Ag and $\mathrm{Ba}$ atoms -are depicted in Figure 4. The anionic building stone, $\left[\mathrm{Cr}\left(\mathrm{C}_{2} \mathrm{O}_{4}\right)_{3}\right]^{3-}$, functions as a metalloligand, or else, as an internetting bridge. Hence, this internetting bridge interconnects, across its $\mathrm{O}$ atoms, the three independent sites $\mathrm{Cr}, \mathrm{Ag} 1 / \mathrm{Ba} 1$ and $\mathrm{Ag} 2 / \mathrm{Ba} 2$ into a three-dimensional polymeric neutral host lattice network that surrounds water-filled channels.

The Cr center (Figure 4(a)) is pseudo-octahedrally chelated by three oxalato ligands with helical orientation, coordination to the metal occurring across the six deprotonated "internal" (hydroxylato) O atoms (O1, O3, O4, O6, O7, O8), and giving rise to $\mathrm{Cr}-\mathrm{O}$ bond lengths and $\mathrm{O}-\mathrm{Cr}-\mathrm{O}$ bond angles which fit well within the ranges of previous results [8]-[11] [17].

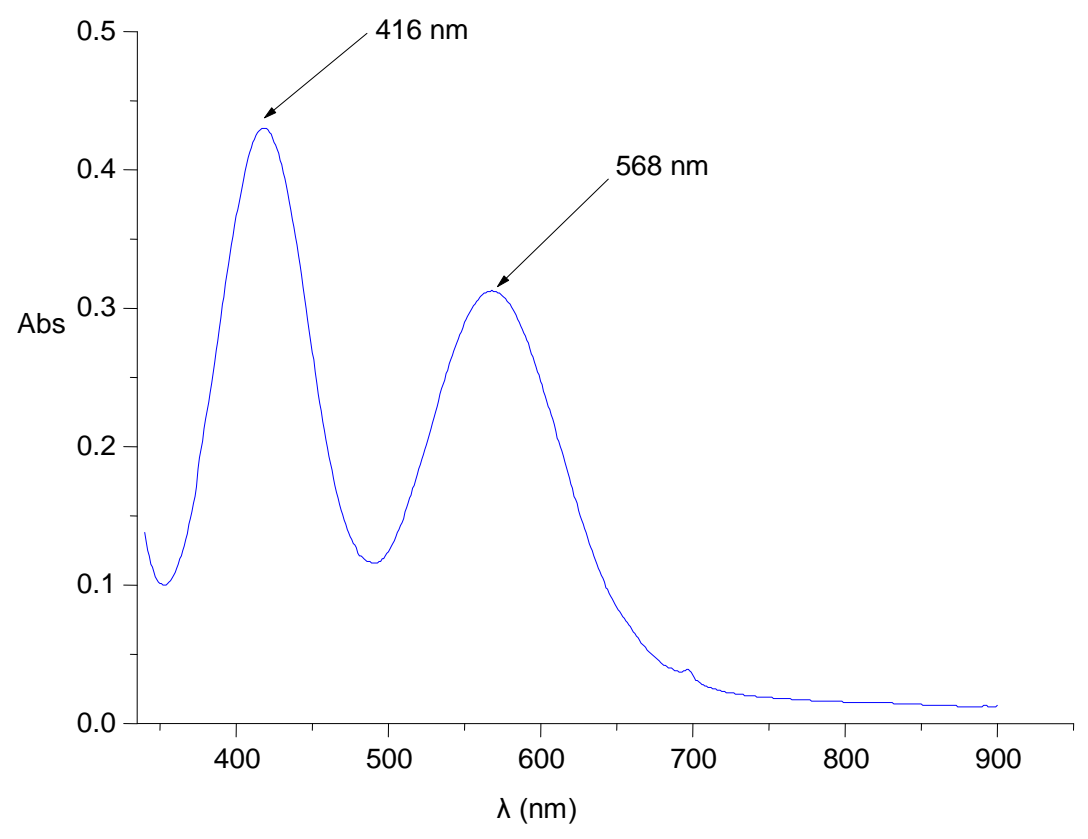

Figure 2. Electronic absorption spectrum of compound 1. 


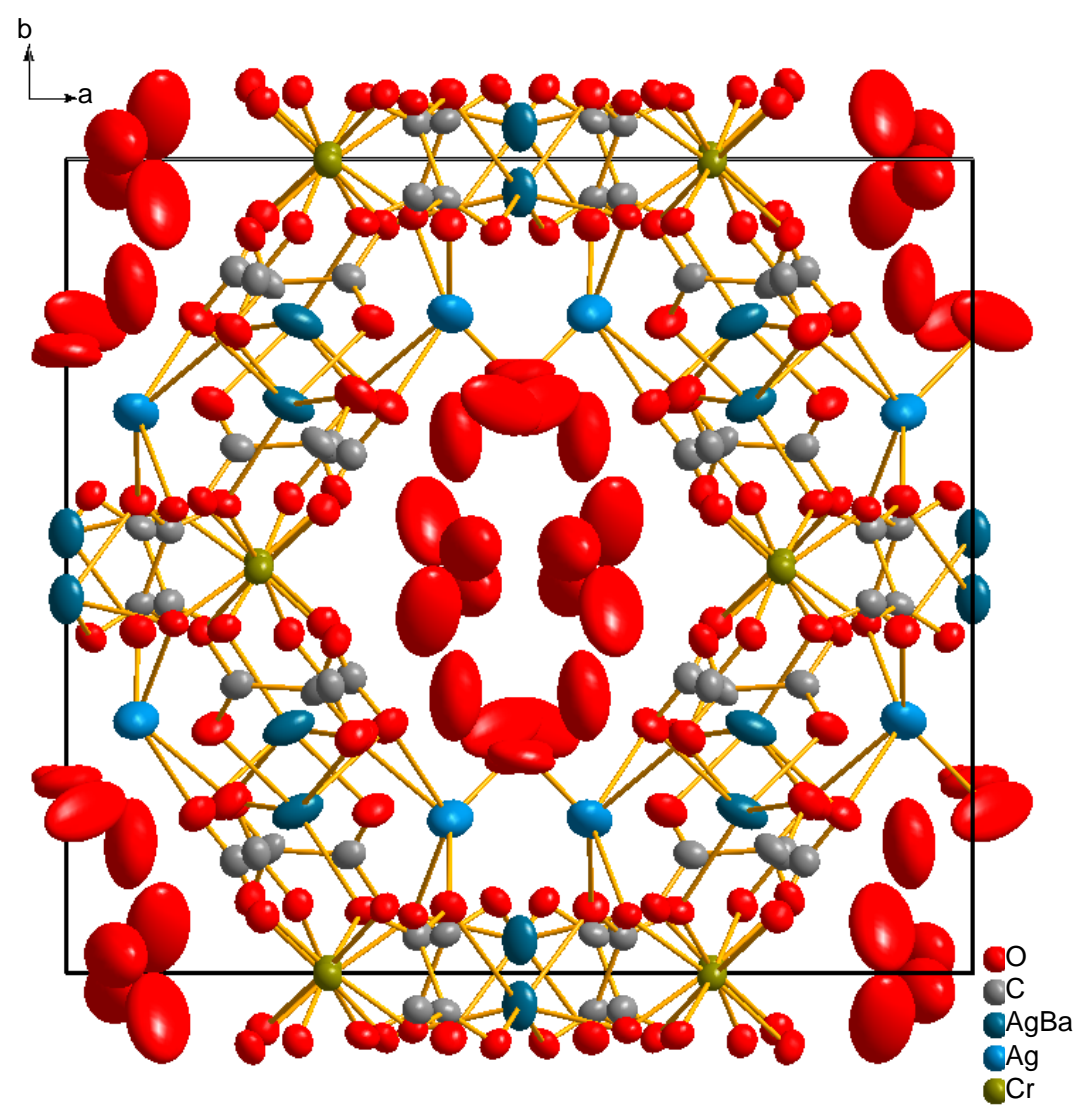

Figure 3. Ball-and-stick representation of the unit cell of 1 projected down [001] highlighting the water molecules within the tubular channel and showing that the host lattice consists exclusively of Ag and Ba cations and $\left[\mathrm{Cr}\left(\mathrm{C}_{2} \mathrm{O}_{4}\right)_{3}\right]^{3-}$ complex anions.

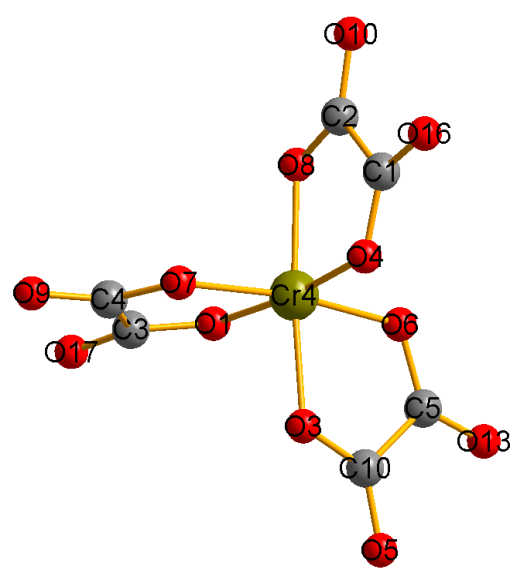

(a)

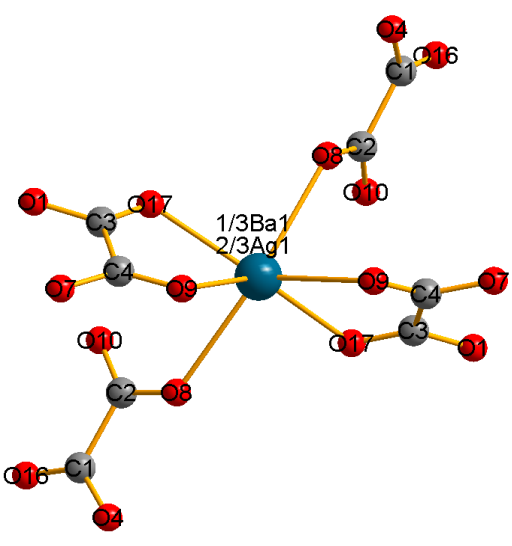

(b)

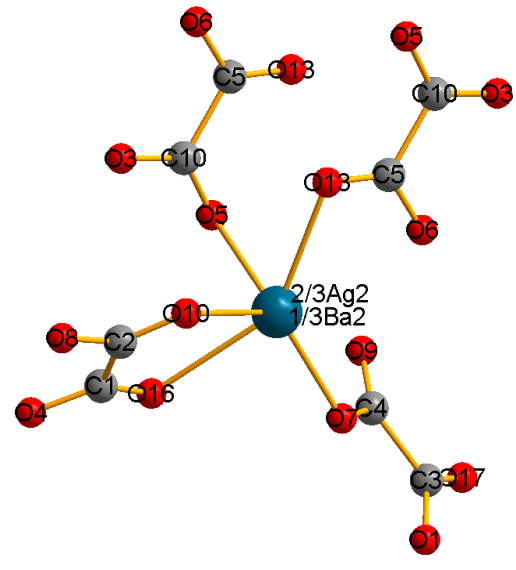

(c)

Figure 4. Coordination polyhedra around the different metallic centers in 1: $\mathrm{Cr}(\mathrm{a}), \operatorname{Ag} 1 / \mathrm{Ba} 1$ (b) and Ag2/Ba2 (c).

The coordination geometry around Ag1/Ba1 (Figure 4(b)) is a severely distorted octahedron involving four carbonyl $\mathrm{O}$ atoms (O9, O9i, O17, O17i) in the equatorial plane and two $\mathrm{O}$ atoms $(\mathrm{O} 8, \mathrm{O} 8 \mathrm{i})$ in the axial positions. Ag1 and Ba1 ions are statistically disordered [ratio 0.667(6):0.333(6)] on the same crystallographic site. All the Ag-O lengths of this octahedron are different with the values ranging from 2.328(3) to 2.559(4) $\AA$ but are comparable with reported values [8]-[10].

The Ag2/Ba2 site (Figure 4(c)) experiences pentacoordination—not tetracoordination like in the structures 
reported by Dean et al. [7] — due to one chelation via the $\mathrm{O}$ atoms (O10, O16), and to three monodentate linkages across O5, $\mathrm{O} 7$ and $\mathrm{O} 13$. Bond lengths and bond angles for the coordination sphere around Ag2 diverge markedly from one another just as previously reported [9] [10]. Ag2 and Ba2 ions are statistically disordered [ratio 0.667(8):0.333(8)] on the same crystallographic site.

The bulk structure of $\mathbf{1}$ is consolidated by $\mathrm{O}-\mathrm{H} \cdots \mathrm{O}$ bridgings within the nanochannels and by coulombic interactions.

In this new member of open framework silver-oxalatochromate(III) compounds, $\mathrm{Ba}_{0.5} \mathrm{Ag}_{2}\left[\mathrm{Cr}\left(\mathrm{C}_{2} \mathrm{O}_{4}\right)_{3}\right] \cdot 5 \mathrm{H}_{2} \mathrm{O}$ (1), cancellation of the negative charge of the lattice grid with chemical composition $\left[\mathrm{Ag}_{2} \mathrm{Cr}\left(\mathrm{C}_{2} \mathrm{O}_{4}\right)_{3}\right]^{-}$is realized by $0.5 \mathrm{Ba}^{2+}$ ion. This $\mathrm{Ba}^{2+}$ ion can be easily replaced by other cations and even by protons through metathetic syntheses. Such materials in which $\mathrm{Ba}^{2+}$ cations are solely replaced by protons are expected to exhibit very high proton conductivity provided that the intervening $\mathrm{H}_{3} \mathrm{O}^{+}$ions are incorporated within the nanochannels and not into the Ag-Cr-oxalate host lattice [8] [18]. Work on this theme is now one of our main focuses.

\section{Conclusion}

The compound, $\mathrm{Ba}_{0.5} \mathrm{Ag}_{2}\left[\mathrm{Cr}\left(\mathrm{C}_{2} \mathrm{O}_{4}\right)_{3}\right] \cdot 5 \mathrm{H}_{2} \mathrm{O}$, isolated from aqueous solution as dark-violet needles, is a novel nanostructured silver-deficient salt hosting $\mathrm{H}_{2} \mathrm{O}$-guest molecules. Following these results which confirm the great flexibility of synthetic manoeuvres for the construction of silver-oxalatometalate(III) assemblies, our future works will doubtless target the synthesis of other members of this family of open-framework coordination polymers, with the main objective of cancelling the negative charge of the host lattice grid $\left[\mathrm{Ag}_{2} \mathrm{Cr}^{\mathrm{III}}\left(\mathrm{C}_{2} \mathrm{O}_{4}\right)_{3}\right]^{-}$by hydronium $\left(\mathrm{H}_{3} \mathrm{O}^{+}\right)$ions solely. Evidence of the protonic charge allowed to migrate very fast up and down within the "water-streams" in the channels opens the door into the fascinating family of materials that may be dubbed Nanochannelled One-dimensional Proton Conducting Solids (1D-PCS). Progress in this research line will likely continue in the near future.

\section{Acknowledgements}

We thank Prof. Boniface P.T. Fokwa for Single crystal X-ray diffraction measurement and structure determination during his stay at Aachen University (Germany). We are grateful to Prof. Michel M. Bélombé for fruitful discussions.

\section{References}

[1] Cheetham, A.K., Férey, G. and Loiseau, T. (1999) Open Framework Inorganic Materials. Angewandte Chemie International Edition, 38, 3268-3292. http://dx.doi.org/10.1002/(SICI)1521-3773(19991115)38:22<3268::AID-ANIE3268>3.0.CO;2-U

[2] Lee, J.Y., Farha, O.K., Roberts, J., Scheidt, K.A., Nguyen, S.T. and Hupp, J.T. (2009) Metal-Organic Framework Materials as Catalysts. Chemistry Society Reviews, 38, 1450-1459. http://dx.doi.org/10.1039/b807080f

[3] Zhang, X.M., Wang, Y.Q., Wang, K., Gao, E.Q. and Liu, C.M. (2011) Metamagnetism and Slow Magnetic Dynamics in an Antiferromagnet Composed of Cobalt(II) Chains with Mixed Azide-Carboxylate Bridges. Chemistry Communications, 47, 1815-1817. http://dx.doi.org/10.1039/C0CC04492J

[4] Coe, B.J., Foxon, S.P., Harper, E.C., Helliwell, M., Raftery, J., Swanson, C.A., Brunschwig, B.S., Clays, K., Franz, E., Garin, J., Orduna, J., Horton, P.N. and Hursthouse, M.B. (2010) Evolution of Linear Absorption and Nonlinear Optical Properties in V-Shaped Ruthenium(II)-Based Chromophores, Journal of the American Chemical Society, 132, 17061723. http://dx.doi.org/10.1021/ja908667p

[5] Yaghi, O.M., O’Keeffe, M., Ockwig, N.W., Chae, H.K., Eddaoudi, M. and Kim, J. (2003) Reticular Synthesis and the Design of New Materials. Nature, 423, 705-714. http://dx.doi.org/10.1038/nature01650

[6] Lim, C.S., Schnobrich, J.K., Wong-Foy, A.G. and Matzger, A.J. (2010) Metal-Dependent Phase Selection in Coordination Polymers Derived from a $C_{2 v}$-Symmetric Tricarboxylate. Inorganic Chemistry, 49, 5271-5275. http://dx.doi.org/10.1021/ic100378p

[7] Dean, P.A.W., Craig, D., Dance, I., Russell, V. and Scudder, M. (2004) A Variable Ag-Cr-Oxalate Channel Lattice: $\left[\mathrm{M}_{\mathrm{x}} \mathrm{Ag}_{0.5-\mathrm{x}}\left(\mathrm{H}_{2} \mathrm{O}\right)_{3}\right] @\left[\mathrm{Ag}_{2.5} \mathrm{Cr}\left(\mathrm{C}_{2} \mathrm{O}_{4}\right)_{3}\right], \mathrm{M}=\mathrm{K}, \mathrm{Cs}$, Ag. Inorganic Chemistry, 43, 443-449. http://dx.doi.org/10.1021/ic034988k

[8] Bélombé, M.M., Nenwa, J., Mbiangué, Y.A., Gouet, B., Majoumo, F., Hey-Hawkins, E. and Lönnecke, P. (2009) Water-Filled Pseudo-Nanotubes in $\mathrm{Ag}_{11.60} \mathrm{H}_{0.40}\left[\mathrm{Cr}\left(\mathrm{C}_{2} \mathrm{O}_{4}\right)_{3}\right]_{4} \cdot 15 \mathrm{H}_{2} \mathrm{O}$ : Synthesis, Characterization and X-Ray Structure. In- 
organica Chimica Acta, 362, 1-4. http://dx.doi.org/10.1016/j.ica.2007.03.003

[9] Nenwa, J., Gouet, B., Djonwouo, P.L. and Fokwa, B.P.T. (2012) Synthesis, X-Ray Structure and Spectroscopic Characterization of a Non-Stoichiometric Nanostructured Silver Salt Hosting Water-Guest Molecules. Research Journal of Chemistry and Environment, 16, 111-115.

[10] Gouet, B., Signé, M., Nenwa, J. and Fokwa, B.P.T. (2013) Synthesis, Crystal Structure and Spectroscopic Characterization of an Oxalato Bridged Silver-Deficient Chromium(III) Salt with Water-Filled Nanochannels. Research Journal of Chemistry and Environment, 17, 57-63.

[11] Bélombé, M.M., Nenwa, J., Tene, O.T. and Fokwa, B.P.T. (2010) Synthesis, X-Ray Structure and Thermal Behavior of Isomorphous Silver-Deficient Channel Lattice Frameworks with General Formula $\left[\left(\mathrm{Ag}_{0.25} / \mathrm{M}_{0.25}\right)\left(\mathrm{H}_{2} \mathrm{O}\right)\right] @\left[\mathrm{Ag}_{2} \mathrm{M}\left(\mathrm{C}_{2} \mathrm{O}_{4}\right)_{3}\right] \cdot 4 \mathrm{H}_{2} \mathrm{O}\left(\mathrm{M}=\mathrm{Co}^{\mathrm{III}}, \mathrm{Cr}^{\mathrm{III}}\right)$. Global Journal of Inorganic Chemistry, 1, 34-41.

[12] Bailar Jr, J.C. and Jones, E.M. (1939) Trioxalato Salts. Inorganic Syntheses, 1, 35-38. http://dx.doi.org/10.1002/9780470132326.ch13

[13] SMART \& SAINT (2003) Software Reference Manual, Version 6.45. Bruker Analytical X-Ray Systems, Inc., Madison, USA.

[14] Siemens Inc., SAINT (1997) Area-Detector Integration Software, Version 6.01, Siemens. Industrial automation, Inc., Madison, Wisconsin, USA.

[15] Sheldrick, G.M. (2010) SADABS, Program for Empirical Absorption Correction of Area Detector Data. University of Göttingen, Göttingen, Germany.

[16] Sheldrick, G.M. (2008) A Short History of SHELX. Acta Crystallographica Section A, 64, 112-122. http://dx.doi.org/10.1107/S0108767307043930

[17] Bélombé, M.M., Nenwa, J., Mbiangué, Y.A., Evina-Nnanga, G., Mbomékallé, I.M., Hey-Hawkins, E., Lönnecke, P. and Majoumo, F. (2003) Unusual Aquation of $\mathrm{Ba}^{2+}$ Ions in the Solid State: Synthesis and X-Ray Structural and Spectroscopic Characterization of the Novel Polymeric Complex Salt of Empirical Formula $\left\{\mathrm{Ba}_{6}\left(\mathrm{H}_{2} \mathrm{O}\right)_{17}\left[\mathrm{Cr}(\mathrm{ox})_{3}\right]_{4}\right\} \cdot 7 \mathrm{H}_{2} \mathrm{O}$ (ox = Oxalate Dianion). Dalton Transactions, 2117-2118. http://dx.doi.org/10.1039/b302489j

[18] Mbiangué, Y.A., Nenwa, J., Bélombé, M.M., Ngoune, J. and Álvarez, E. (2012) Hydrogen-Bonded Pillars of Alternating Chiral Complex Cations and Anions: 2. Synthesis, Characterization and $\mathrm{X}$-Ray Structure of Isomorphous catena- $\left\{\left(\mathrm{H}_{3} \mathrm{O}\right)\left[\mathrm{K}\left(\mathrm{H}_{2} \mathrm{O}\right)_{3}\right] @\left[\mathrm{Ni}\left(\mathrm{H}_{2} \mathrm{Oxado}\right)_{3}\right]_{2}\left[\mathrm{Cr}\left(\mathrm{C}_{2} \mathrm{O}_{4}\right)_{3}\right]_{2} \cdot 3 \mathrm{H}_{2} \mathrm{O}\right\}$ and catena- $\left\{\left(\mathrm{H}_{3} \mathrm{O}\right)\left[\mathrm{Li}\left(\mathrm{H}_{2} \mathrm{O}\right)_{3}\right] @\left[\mathrm{Ni}\left(\mathrm{H}_{2} \text { oxado }\right)_{3}\right]_{2}\left[\mathrm{Cr}\left(\mathrm{C}_{2} \mathrm{O}_{4}\right)_{3}\right]_{2} \cdot 3 \mathrm{H}_{2} \mathrm{O}\right\}$. ScienceJet, 1, 1-9. 